\title{
Amharic Language
}

National Cancer Institute

\section{Source}

National Cancer Institute. Amharic Language. NCI Thesaurus. Code C153833.

A Semitic language spoken as a first language by the Amharas ethnic group and which serves as the official working language of Ethiopia. 